\title{
Perbedaan proporsi stunting pada anak usia 12-24 bulan berdasarkan pemanfaatan pelayanan posyandu di Kabupaten Jayapura, Papua
}

Difference of stunting proportion on 12-24 months children according to posyandu service utilization in Jayapura, Рариа

\author{
Yulia Nuradha Kartosiana Wasaraka ${ }^{1}$, Endy Paryanto Prawirohartono ${ }^{2}$, Yati Soenarto $^{2}$ \\ ${ }^{1}$ Minat Utama Gizi dan Kesehatan, Program Studi S2 Ilmu Kesehatan Masyarakat Fakultas Kedokteran Universitas Gadjah Mada \\ ${ }^{2}$ Departemen Ilmu Kesehatan Anak, Fakultas Kedokteran Universitas Gadjah Mada
}

\begin{abstract}
Background: Stunting according to World Health Organization's standard is a linear growth failure identified by Z-score value of proportioned height by age (Body Height/Age) that less than -2 of standard deviation. Indonesia has the fifth largest number of stunted children in the world right after India, Nigeria, Pakistan and China. Posyandu service utilization is one of stunting determinants. Number of visits and the activity of infants in using Posyandu services will help the observation of children's health and nutrition status. Through thoroughly observation chronically malnourished and stunting could be earlier identified, thus the growth failure could be prevented. Objective: to identify the stunting proportion difference of 12-24 months children according to Posyandu services use. Method: Study was conducted by using observational method and cross-sectional research design. Subjects of study are 12-24 month children in Jayapura Regency. Cluster random sampling method was used to identify 313 children as samples. Observation data was analyzed by using chi-square test and fisher exact test due to a not normally distributed population. Results: There are $19.8 \%$ samples identified as stunted children. Chi-square test and fisher exact test showed that there is no significant difference in stunting proportion according to Posyandu service utilization ( $p>0.05)$. Meanwhile there is significant difference between number of stunting and number of URI (Upper respiratory tract Infection) $(p=0.017)$ and mothers nutrition knowledge $(p=0.025)$. Conclusion: There is not any difference in stunting number proportion according to Posyandu services utilization.
\end{abstract}

KEY WORDS: posyandu; posyandu service utilization; stunting

\begin{abstract}
ABSTRAK
Latar belakang: Stunting adalah gangguan pertumbuhan linier yang ditunjukkan dengan nilai Z-score tinggi badan menurut usia (TB/U) kurang dari -2 standar deviasi (SD) berdasarkan standar World Health Organization. Indonesia merupakan negara kelima terbesar dengan anak stunted setelah India, Nigeria, Pakistan, dan China. Pemanfaatan pelayanan posyandu merupakan salah satu determinan terjadinya stunting pada balita. Keaktifan balita ke posyandu sangat besar pengaruhnya terhadap pemantauan status gizi. Memantau pertumbuhan balita di posyandu merupakan upaya untuk mendeteksi dini terjadinya gangguan pertumbuhan sehingga dapat dilakukan pencegahan terjadinya balita stunting. Tujuan: Mengetahui perbedaan proporsi stunting pada anak usia 12-24 bulan berdasarkan pemanfaatan pelayanan posyandu di Kabupaten Jayapura. Metode: Jenis penelitian observasional dengan desain cross-sectional. Subyek penelitian anak usia 12-24 bulan di Kabupaten Jayapura. Pemilihan sampel menggunakan teknik cluster random sampling dengan jumlah sampel 313 anak. Data dianalisis dengan menggunakan uji statistik Chi-Square dan fisher exact. Hasil: Terdapat 19,8\% anak yang tergolong stunting. Hasil analisis menunjukkan bahwa tidak terdapat perbedaan bermakna proporsi stunting berdasarkan pemanfaatan pelayanan posyandu $(\mathrm{p}>0,05)$. Namun, terdapat perbedaan yang bermakna antara stunting dengan kejadian infeksi saluran pernapasan akut $(\mathrm{ISPA})(\mathrm{p}=0,017)$ dan pengetahuan gizi ibu $(\mathrm{p}=0,025)$. Simpulan: Tidak terdapat perbedaan proporsi stunting berdasarkan pemanfaatan pelayanan posyandu.
\end{abstract}

KATA KUNCI: posyandu; pemanfaatan pelayanan posyandu; stunting

Korespondensi: Sinta Mukti Permatasari, Minat Utama Gizi dan Kesehatan, Program Studi S2 Ilmu Kesehatan Masyarakat Fakultas Kedokteran Universitas Gadjah Mada, Jl. Farmako, Sekip Utara, Yogyakarta 55281,e-mail: yuliankwasaraka@gmail.com 


\section{PENDAHULUAN}

Stunting adalah gangguan pertumbuhan linier yang disebabkan adanya malnutrisi asupan zat gizi kronis dan/atau penyakit infeksi kronis maupun berulang yang ditunjukkan dengan nilai Z-score tinggi badan menurut usia (TB/U) kurang dari -2 standar deviasi (SD) berdasarkan standar World Health Organization (1). Proses untuk menjadi seorang anak bertubuh pendek (stunting) atau yang disebut kegagalan pertumbuhan (growth faltering) dimulai dalam rahim. Pada saat anak melewati usia dua tahun, maka sudah terlambat untuk memperbaiki kerusakan pada tahun-tahun awal kehidupan (2).

Indonesia merupakan negara kelima terbesar dengan anak stunted setelah India, Nigeria, Pakistan dan China (3). Hasil Riset kesehatan dasar tahun 2013 menunjukkan bahwa prevalensi anak balita Indonesia yang mengalami stunting relatif tinggi yaitu sebesar $37,2 \%$ dan prevalensi anak balita stunted di Provinsi Papua mengalami kenaikan dari $28,3 \%$ pada tahun 2010 menjadi 40\% pada tahun 2013 (4). Anak yang stunting menampilkan performa yang buruk pada tes perhatian, memori bekerja, memori belajar, dan kemampuan visuospasial (5). Anak yang mengalami kegagalan pertumbuhan pada dua tahun pertama meningkatkan risiko penyakit yang serius pada akhir masa anak-anak dan perkembangan penyakit kronis di masa dewasa (6).

Pemanfaatan pelayanan posyandu merupakan salah satu determinan terjadinya stunting pada balita. Keaktifan balita ke posyandu sangat besar pengaruhnya terhadap pemantauan status gizi. Memantau pertumbuhan balita di posyandu merupakan upaya untuk mendeteksi dini terjadinya gangguan pertumbuhan sehingga dapat dilakukan pencegahan terjadinya balita stunting (7). Selain pemantauan pertumbuhan, di posyandu balita akan memperoleh imunisasi, kapsul vitamin A, penyuluhan gizi kesehatan, makanan tambahan, dan penanggulangan diare (8). Kunjungan posyandu kurang dari dua kali dalam enam bulan terakhir dapat meningkatkan risiko terjadinya stunting 2,57 kali lebih besar (9). Balita yang tidak mendapat imunisasi dan kapsul vitamin A memiliki risiko lebih besar untuk menjadi stunting (10-12).

Provinsi Papua merupakan provinsi dengan cakupan (D/S) rendah yaitu 44,1\% (target 70\%) pada tahun 2011 (13). Hasil Riskesdas tahun 2013 menunjukkan bahwa frekuensi balita di Provinsi Papua yang melakukan penimbangan rutin ( $>4$ kali) dan memperoleh kapsul vitamin A dalam kurun waktu 6 bulan terakhir adalah 20\% dan 54\%. Provinsi Papua merupakan provinsi dengan cakupan imunisasi lengkap terendah di Indonesia yaitu hanya sebesar 29,2\% (4). Mengingat kejadian stunting dapat merugikan masa depan anak bangsa khususnya anak Papua, maka penelitian ini perlu untuk dilakukan untuk mengetahui perbedaan proporsi stunting pada anak usia 12-24 bulan berdasarkan pemanfaatan pelayanan posyandu di Kabupaten Jayapura, Papua.

\section{BAHAN DAN METODE}

Jenis penelitian ini merupakan studi observasional dengan rancangan cross-sectional study. Penelitian ini dilakukan di Kabupaten Jayapura, Provinsi Papua pada bulan Mei-Agustus 2014. Subjek penelitian adalah anak usia 12-24 di Kabupaten Jayapura, Provinsi Papua yang memenuhi kriteria inklusi dan ekslusi. Ibu atau pengasuh utama dari subjek penelitian merupakan responden. Kriteria inklusi subjek penelitian adalah anak usia 1224 bulan, anak yang orang tua/wali mengizinkan untuk menjadi subjek penelitian dengan menandatangani informed consent sedangkan kriteria ekslusi subjek adalah anak yang menderita cacat fisik. Jumlah subjek pada penelitian adalah 313 anak dengan teknik pengambilan sampel menggunakan cluster random sampling. Variabel terikat adalah stunting, variabel bebas pemanfaatan pelayanan posyandu (frekuensi kunjungan posyandu, penimbangan, penerimaan kapsul vitamin A, penerimaan imunisasi, PMT, penanggulangan diare dan penyuluhan gizi) serta variabel luar adalah penyakit infeksi dan pengetahuan gizi ibu.

Subyek penelitian dikategorikan menderita stunting ketika $z$-score $\mathrm{PB} / \mathrm{U}<-2 \mathrm{SD}$ dan dikategorikan normal bila $z$-score $\mathrm{PB} / \mathrm{U} \geq-2 \mathrm{SD}$ (14). Pemanfaatan posyandu yang tergambar dari frekuensi kunjungan posyandu didefinisikan sebagai frekuensi kunjungan ibu dan anak usia 12-24 bulan ke posyandu dalam kurun waktu enam bulan terakhir dan dibagi menjadi dua kategori yaitu kunjungan 4-6 kali dan kunjungan 1-3 kali (15). Penimbangan balita adalah penimbangan berat 
badan anak usia 12-24 bulan di posyandu dalam kurun waktu enam bulan terakhir dan dibagi menjadi tiga kateori yaitu penimbangan $\geq 4$ kali, penimbangan 1-3 kali, dan penimbangan 0 kali (16).

Riwayat diare adalah riwayat penyakit diare (mencret atau buang air besar lebih dari tiga sampai empat kali dalam sehari dengan konsistensi cair dan berlendir) yang pernah diderita oleh anak usia 12-24 bulan dalam kurun waktu dua minggu terakhirdan dibagi menjadi dua kategori yaitu anak pernah menderita diare dua minggu terakhir dan anak tidak pernah menderita diare dua minggu terakhir (17). Kemudian, riwayat ISPA adalah riwayat penyakit infeksi saluran pernafasan akut (batuk disertai sesak nafas, demam, panas dan beringus) yang pernah diderita oleh anak usia 12-24 bulan dalam kurun waktu dua minggu terakhir (17). Pengetahuan gizi ibu adalah penguasaan ibu terhadap pengetahuan yang berhubungan dengan sumber dan fungsi zat gizi, ASI eksklusif, makanan pendamping ASI (MP-ASI), dan pelayanan posyandu. Soal pengetahuan gizi diberikan dalam bentuk correct answer multiplechoice, jika benar bernilai 1 dan salah/tidak tahu bernilai 0. Pengetahuan gizi dikategorikan menjadi dua yaitu baik (skor $\geq 77 \%$ ) dan kurang baik (skor $<77 \%$ ) (18).

Penelitian ini menggunakan beberapa instrumen antara lain papan pengukur panjang badan untuk anak dibawah 24 bulan dan kuesioner terstruktur. Cara pengumpulan data antara lain data panjang badan diperoleh melalui pengukuran menggunakan papan pengukur panjang badan. Data identitas subjek penelitian dan data mengenai pemanfaatan pelayanan posyandu diperoleh melalui wawancara dengan responden penelitian menggunakan kuesioner terstruktur. Uji validitas dan reabilitas kuesioner pengetahuan gizi dilakukan pada 30 orang responden (ibu balita) di kecamatan yang berdekatan dan memiliki karakteristik yang hampir sama dengan lokasi penelitian. Analisis bivariat dilakukan untuk mengetahui perbedaan proporsi kejadian stunting berdasarkan pemanfaatan pelayanan posyandu menggunakan uji statistik Chi-Square dan Fisher exact. Penelitian ini telah mendapatkan persetujuan etik dari Komisi Etik Penelitian Kedokteran dan Kesehatan Fakultas Kedokteran Universitas Gadjah Mada.

\section{HASIL}

Subjek penelitian terdiri dari 313 anak usia 1224 bulan di Kabupaten Jayapura. Sebagian besar anak stunting berjenis kelamin laki-laki $(58,1 \%)$ dan anak normal berjenis kelamin perempuan $(53,4 \%)$. Panjang badan menurut umur subyek sebagian besar memiliki Z-score $\geq$-2SD (normal) (80,2\%) dan anak stunting (19,8\%). Sebagian besar usia ibu berkisar antara 20-34 tahun $(82,7 \%)$, baik ibu yang memiliki anak normal maupun stunting. Hal ini menunjukkan bahwa masih banyak ibu yang berada di rentang usia subur. Jumlah anak dalam keluarga yang berjumlah antara 0 sampai 2 lebih banyak dalam penelitian ini yaitu $68,4 \%$, baik dalam kelompok normal maupun stunting. Sebagian besar pekerjaan ibu adalah ibu rumah tangga atau tidak bekerja $(81,8 \%)$ dan berpendidikan terakhir yaitu SMA $(60,7 \%)$. Umumnya pekerjaan ayah adalah pegawai

Tabel 1. Karakteristik umum subjek penelitian

\begin{tabular}{|c|c|c|c|}
\hline Karakteristik & $\begin{array}{c}\text { Stunting } \\
(\mathrm{n}=62 \\
\%)\end{array}$ & $\begin{array}{c}\text { Normal } \\
(n=251 \\
\%)\end{array}$ & $\begin{array}{c}\text { Total } \\
(n=313, \%)\end{array}$ \\
\hline \multicolumn{4}{|l|}{ Jenis kelamin } \\
\hline Perempuan & $26(41,9)$ & $134(53,4)$ & $160(51,1)$ \\
\hline Laki-laki & $36(58,1)$ & $117(46,6)$ & $153(48,9)$ \\
\hline \multicolumn{4}{|l|}{ Usia ibu (tahun) } \\
\hline$<20$ & $2(3,2)$ & $5(2,0)$ & $7(2,2)$ \\
\hline $20-34$ & $54(87,1)$ & $205(81,7)$ & $259(82,7)$ \\
\hline$\geq 35$ & $6(9,7)$ & $41(16,3)$ & $47(15,0)$ \\
\hline \multicolumn{4}{|c|}{ Jumlah anak per keluarga } \\
\hline $0-2$ & $36(58,1)$ & $178(70,9)$ & $214(68,4)$ \\
\hline $3-4$ & $18(29)$ & $52(20,7)$ & $70(22,4)$ \\
\hline$\geq 5$ & $8(12,9)$ & $21(8,4)$ & $29(9,3)$ \\
\hline \multicolumn{4}{|l|}{ Pendidikan ibu } \\
\hline Tidak Sekolah & $1(1,6)$ & $2(0,8)$ & $3(1,0)$ \\
\hline $\mathrm{SD}$ & $8(12,9)$ & $17(6,8)$ & $25(8,0)$ \\
\hline SMP & $14(22,6)$ & $35(13,9)$ & $49(15,7)$ \\
\hline SMA & $37(59,7)$ & $153(61)$ & $190(60,7)$ \\
\hline PT & $2(3,2)$ & $44(17,5)$ & $46(14,7)$ \\
\hline \multicolumn{4}{|l|}{ Pekerjaan ibu } \\
\hline Ibu rumah tangga & $55(88,7)$ & $201(80,1)$ & $256(81,8)$ \\
\hline Lainnya & $7(11,3)$ & $50(19,9)$ & $57(18,2)$ \\
\hline \multicolumn{4}{|l|}{ Pekerjaan ayah } \\
\hline Tidak bekerja & $9(14,5)$ & $23(9,2)$ & $32(10,2)$ \\
\hline PNS/TNI/POLRI & $5(8,1)$ & $76(30,3)$ & $81(25,9)$ \\
\hline Pegawai swasta & $28(45,2)$ & $107(42,6)$ & $135(43,1)$ \\
\hline Wiraswasta/Jasa & $0(0)$ & $8(3,2)$ & $8(2,6)$ \\
\hline $\begin{array}{l}\text { Petani/nelayan/ } \\
\text { buruh/ojek }\end{array}$ & $20(32,2)$ & $37(14,7)$ & $57 \quad(18,2)$ \\
\hline
\end{tabular}


Tabel 2. Status stunting berdasarkan pemanfaatan pelayanan posyandu

\begin{tabular}{|c|c|c|c|c|}
\hline Variabel & $\begin{array}{l}\text { Stunting } \\
(\mathrm{n}=62, \%)\end{array}$ & $\begin{array}{c}\text { Normal } \\
(\mathrm{n}=\mathbf{2 5 1}, \%)\end{array}$ & $\begin{array}{c}\text { Total } \\
(\mathrm{n}=\mathbf{3 1 3})\end{array}$ & p \\
\hline \multicolumn{5}{|l|}{ Kunjungan posyandu } \\
\hline $1-3$ kali & $8(12,9)$ & $35(13,9)$ & $43(13,7)$ & \multirow[t]{2}{*}{0,831} \\
\hline 4-6 kali & $54(87,1)$ & $216(86,1)$ & $270(86,3)$ & \\
\hline \multicolumn{5}{|l|}{ Penimbangan } \\
\hline 0 kali & $2(3,2)$ & $4(1,6)$ & $6(1,9)$ & \multirow{3}{*}{0,501} \\
\hline $1-3$ kali & $6(9,7)$ & $31(12,3)$ & $37(11,8)$ & \\
\hline$\geq 5$ kali & $54(87,1)$ & $216(86,1)$ & $270(86,3)$ & \\
\hline \multicolumn{5}{|l|}{ Vitamin A } \\
\hline Menerima vitamin A & $51(82,3)$ & $222(88,4)$ & $273(87,2)$ & \multirow[t]{2}{*}{0,191} \\
\hline Tidak menerima vitamin A & $11(17,7)$ & $29(11,6)$ & $40(12,8)$ & \\
\hline \multicolumn{5}{|l|}{ Imunisasi } \\
\hline Tidak menerima imunisasi & $0(0)$ & $0(0)$ & $0(0)$ & \multirow{3}{*}{0,368} \\
\hline Menerima 1-6 dari ketujuh imunisasi & $5(8,1)$ & $13(5,2)$ & $18(5,8)$ & \\
\hline Menerima semua imunisasi & $57(91,9)$ & $238(94,8)$ & $295(94,2)$ & \\
\hline \multicolumn{5}{|l|}{ PMT } \\
\hline Menerima PMT & $50(80,6)$ & $187(74,5)$ & $237(75,7)$ & \multirow[t]{2}{*}{0,312} \\
\hline Tidak menerima PMT & $12(19,4)$ & $64(25,5)$ & $76(24,3)$ & \\
\hline \multicolumn{5}{|l|}{ Penanggulangan Diare } \\
\hline Membawa anak ke pelayanan kesehatan & $50(80,6)$ & $218(86,8)$ & $268(85,6)$ & \multirow[t]{2}{*}{0,212} \\
\hline $\begin{array}{l}\text { Tidak membawa anak ke pelayanan } \\
\text { kesehatan }\end{array}$ & $12(19,4)$ & $33(13,2)$ & $45(14,4)$ & \\
\hline \multicolumn{5}{|l|}{ Penyuluhan Gizi } \\
\hline Pernah mendapatkan penyuluhan gizi & $38(61,3)$ & $138(55)$ & $176(56,2)$ & \multirow[t]{2}{*}{0,370} \\
\hline Tidak pernah mendapatkan penyuluhan gizi & $24(38,7)$ & $113(45)$ & $137(43,8)$ & \\
\hline
\end{tabular}

swasta $(43,1 \%)$, baik pada kelompok normal maupun stunting (Tabel 1 ).

Tabel 2 menunjukkan bahwa kejadian stunting lebih banyak terdapat pada anak yang berkunjung ke posyandu 4 sampai 6 kali dalam enam bulan terakhir $(87,1 \%)$, begitu pula pada kelompok anak normal $(86,1 \%)$. Sebagian besar anak stunting $(87,1 \%)$ dan normal $(86,1 \%)$ melakukan penimbangan $\geq 5$ kali dalam enam bulan terakhir. Sebagian besar anak stunting $(82,3 \%)$ dan normal $(88,4 \%)$ menerima kapsul vitamin A di posyandu dalam enam bulan terakhir. Hampir semua anak stunting menerima imunisasi lengkap (91,9\%), begitu pula anak normal $(94,8 \%)$ dan tidak ada anak yang tidak pernah menerima imunisasi $(0 \%)$. Sebagian besar anak stunting menerima PMT $(80,6 \%)$, begitu pula anak normal (74,5\%). Sebagian besar ibu membawa anaknya ke tempat pelayanan kesehatan ketika menderita diare $(85,6 \%)$ dan $14,4 \%$ anak yang tidak dibawa ke tempat pelayanan kesehatan/hanya di rumah saja. Sebagian besar ibu pernah memperoleh penyuluhan gizi di posyandu
(56,2\%), baik pada kelompok stunting $(61,3 \%)$ maupun kelompok normal (55\%). Proporsi stunting dan tidak stunting tidak berbeda bermakna menurut kunjungan posyandu, penimbangan balita, penerimaan kapsul vitamin A, penerimaan imunisasi dasar, penerimaan makanan tambahan (PMT), penanggulangan diare, dan penyuluhan gizi dan kesehatan $(\mathrm{p}>0,05)$.

\section{BAHASAN}

Penelitian ini tidak menemukan perbedaan bermakna pada proporsi stunting berdasarkan kunjungan posyandu. Hal ini dapat disebabkan oleh proses terjadinya stunting pada balita telah terjadi sejak di dalam kandungan. Dua trisemester pertama masa kehamilan merupakan periode sensitif bagi pertumbuhan linier janin (19). Pada masa ini, pertumbuhan dan perkembangan janin berkembang pesat sehingga kebutuhan asupan zat gizi sangat tinggi (20). Jika terjadi gangguan pertumbuhan atau stunting yang terbentuk sejak janin sampai dua tahun 
pertama kehidupan akan memberikan dampak kerusakan yang permanen (sulit untuk diperbaiki) dan jangka panjang (irreversible) (21).

Tidak terdapat perbedaan yang bermakna pada proporsi stunting berdasarkan penimbangan balita. Hal ini dapat disebabkan oleh pemantauan berat badan balita melalui penimbangan yang dilakukan di posyandu tidak efektif dapat melihat kejadian stunting. Stunting dapat dilihat jika di posyandu rutin dilakukan pengukuran tinggi badan sehingga akan diketahui sejak dini jika terjadi gangguan pertumbuhan tinggi badan menurut umur. Demikian juga tidak ada perbedaan antara anak yang menerima kapsul vitamin A dan imunisasi di posyandu pada kelompok stunting dan tidak stunting. Di wilayah Kabupaten Jayapura, penerimaan imunisasi dan kapsul vitamin A sudah berjalan efektif, tetapi imunisasi dan vitamin A bukan satu-satunya faktor yang dapat mempengaruhi kejadian stunting pada balita. Kebutuhan vitamin A yang adekuat dan imunisasi lengkap jika tidak dibarengi dengan terpenuhinya kebutuhan asupan energi dan protein maka kejadian stunting akan tetap terjadi. Kurangnya asupan makan dan penyakit infeksi yang berulang merupakan faktor langsung penyebab stunting pada balita (22).

Lebih lanjut, tidak ditemukan adanya perbedaan bermakna proporsi stunting berdasarkan penerimaan PMT di posyandu. Hal ini dapat disebabkan oleh pemberian PMT di posyandu tidak diberikan setiap bulannya sehingga penerimaan PMT tidak konsisten. Jenis PMT yang diberikan juga bervariasi, antara lain bubur kacang hijau, biskuit dan susu. Jenis tersebut belum tentu dapat memenuhi kebutuhan gizi masing-masing individu, apalagi jika pola makan dan asupan gizi balita di rumah tidak seimbang sehingga penerimaan PMT di posyandu tidak efektif dapat mencegah dan memperbaiki status gizi balita stunting. Asupan zat gizi makro maupun mikro harus terpenuhi untuk dapat mencegah terjadinya stunting. Selain itu, jumlah dan jenis makanan, serta frekuensi makan juga berkontribusi terhadap kejadian stunting pada balita $(23,24)$.

Tidak ada perbedaan antara anak yang dibawa atau tidak dibawa ke pelayanan kesehatan saat mengalami diare pada kelompok stunting dan tidak stunting. Hal ini dapat disebabkan oleh anak yang dibawa ke tempat pelayanan kesehatan belum tentu mengalami kesembuhan atau penurunan episode diare dalam satu kali pengobatan, tergantung dari tingkat keparahan diare tersebut, apakah ringan atau berat. Diare dapat disebabkan oleh beberapa jenis virus/bakteri/parasit dan masing-masing jenis tersebut memberikan tingkat keparahan diare yang berbeda-beda (25).

Hasil analisis juga menunjukkan tidak adanya perbedaan bermakna proporsi stunting berdasarkan penyuluhan gizi. Hal ini disebabkan oleh tidak optimalnya fungsi meja 4 di posyandu yaitu pelayanan penyuluhan gizi, padahal kunjungan posyandu merupakan kesempatan untuk memberikan konseling kepada ibu (26). Petugas hanya menegur ibu apabila terjadi penurunan berat badan anak hingga di bawah garis merah. Diperlukan penyuluhan gizi yang rutin dan berkesinambungan untuk dapat meningkatkan pengetahuan ibu mengenai gizi dan kesehatan (27). Pengetahuan gizi ibu memiliki perbedaan yang bermakna terhadap kejadian stunting. Hal ini dapat disebabkan oleh tingkat pengetahuan ibu menentukan perilaku konsumsi pangan. Tingkat pengetahuan ibu bermakna dengan sikap positif terhadap perencanaan dan persiapan makan. Semakin tinggi pengetahuan ibu maka semakin positif sikap ibu terhadap gizi makanan. Ibu yang memiliki pengetahuan gizi baik mampu menyusun menu yang baik dengan memperhitungkan kebutuhan gizi anggota keluarga terutama anak balita agar dapat tumbuh dan berkembang secara optimal (28). Penyebab timbulnya masalah gizi adalah kurangnya pengetahuan gizi masyarakat khususnya ibu yang sebagian besar adalah pengasuh anak (29).

Pada penelitian ini tidak terdapat perbedaan bermakna proporsi stunting berdasarkan kejadian diare. Hal ini dapat disebabkan oleh diare yang diderita balita tidak berlangsung berulang-ulang atau tergolong diare ringan sehingga tidak sampai mengakibatkan balita mengalami dehidrasi berat dan malabsorbsi gizi yang dapat menurunkan status gizinya (30). Berbeda dengan kejadian ISPA yang menunjukkan perbedaan bermakna pada kelompok stunting dan tidak stunting. Hal ini dapat disebabkan ISPA yang dialami balita berlangsung cukup lama atau tidak ditangani dalam waktu lama sehingga frekuensi sakit semakin meningkat (31). Penyakit infeksi yang berlangsung lama akan mengakibatkan 
penurunan nafsu makan, malabsorbsi gizi, dan perubahan metabolisme tubuh yang menyebabkan berkurangnya asupan makanan dan akhirnya berdampak pada status gizi balita (kegagalan pertumbuhan) (32).

Penelitian ini memiliki beberapa kelemahan yaitu penelitian ini tidak mengukur asupan makan (zat gizi) balita sehingga tidak diketahui tingkat asupan zat gizi balita yang dapat mendukung hasil penelitian ini. Penelitian ini juga tidak mengukur frekuensi penerimaan PMT dan penyuluhan gizi di posyandu, episode/durasi diare dan ISPA sehingga tidak diketahui tingkat keparahan penyakit infeksi tersebut.

\section{SIMPULAN DAN SARAN}

Tidak ada perbedaan proporsi stunting berdasarkan pemanfaatan pelayanan posyandu. Sebaiknya di setiap posyandu dilakukan program pengukuran tinggi badan, sehingga status gizi (TB/U) dapat terpantau dengan baik. Penelitian selanjutnya perlu ditambahkan variabel asupan zat gizi untuk mengetahui tingkat asupan zat gizi balita dan frekuensi penyakit infeksi (diare dan ISPA) untuk mengetahui tingkat keparahan penyakit tersebut.

\section{RUJUKAN}

1. World Health Organization (WHO). Nutrition Landscape Information System (NLIS) Country Profile Indicators: Interpretation Guid. Switzerland : WHO Press; 2010.

2. United Nations Children's Fund (UNICEF) Indonesia. Ringkasan Kajian: Gizi Ibu dan Anak; New York: UNICEF; 2012.

3. United Nations Children's Fund (UNICEF). Improving Child Nutrition. New York: UNICEF; 2013.

4. Kemenkes RI. Laporan Hasil Riset Kesehatan Dasar (Riskesdas) Nasional. Jakarta Balai Penelitian dan Pengembangan. Departemen Kesehatan RI; 2013.

5. Kar BR, Rao SL, Chandramouli BA. Cognitive Development in Children with Chronic Protein Energy Malnutrition. Behavior and Brain Function 2008;4(31).

6. Santos IS, Matijasevich A, Domingues MR, Barros AJD, Victora CG, Barros FC. Late Preterm Birth is a Risk Factor for Growth Faltering in Early Childhood: a Cohort Study. BMC Pediatrics 2009;9(71).

7. Kemenkes RI. Panduan Penyelenggaraan Pemberian Makanan Tambahan Pemulihan Bagi Balita Gizi Kurang. Direktorat Jenderal Bina Gizi. Jakarta: Kementerian Kesehatan RI; 2011.
8. Supariasa, Bakri B, Fajar I. Penilaian Status Gizi. Jakarta: EGC; 2001.

9. Reyes H, Perez-Cuevas R, Sandoval A, Castillo R, Santos IJ, Doubova SV, Gutierrez G. The Family as a Determinant of Stunting in Children Living in Conditions of Extreme Poverty: a Case Control Study. BMC Pediatrics 2004;4(57).

10. Shrimpton R, Kachondham Y. Analysing the Causes of Child Stunting in DPRK; UNICEF; 2003.

11. Semba RD, De Pee S, Berger SG, Martini E, O Ricks M, Bloem MW. Malnutrition and Infectious Disease Morbidity Among Children Missed by The Childhood Immunization Program in Indonesia. Southeast Asian Journal Trop Med Public Health 2007;38(1).

12. Berger SG, de Pee S, Bloem MW, Halati S, Semba RD. Malnutrition and Morbidity Are Higher in Children Who Are Missed by Periodic Vitamin A Capsule Distribution for Child Survival in Rural Indonesia. J Nutr 2007;137(5):1328-33.

13. Kemenkes RI. Kinerja Kegiatan Pembinaan Gizi Tahun 2011: Menuju Perbaikan Gizi Perseorangan dan Masyarakat yang Bermutu. Jakarta: Direktorat Jenderal Bina Gizi; 2012.

14. World Health Organization. Child growth standards: Methods and development. Geneva: Department Nutrition for Health and Development; 2006.

15. Anwar F, Khomsan A, Sukandar D, Riyadi H, Mudjajanto ES. High participation in the posyandu nutrition program improved children nutritional status. Nutr Res Pract 2010;4(3):208-14.

16. Kemenkes RI. Laporan hasil riset kesehatan dasar (Riskesdas) Nasional. Jakarta: Balai Penelitian dan Pengembangan. Departemen Kesehatan RI; 2010.

17. Shrimpton R, Kachondham Y. Analysing the causes of child stunting in Democratic Peoples Republic Korea (DPRK). Pyongyang: DPRK; 2003.

18. Djaali dan Mulyono. Pengukuran dalam Bidang Pendidikan. Jakarta: Universitas Negeri Jakarta; 2004.

19. Neufeld LM, Haas JD, Grajeda R, Martorell R. Changes in Maternal Weight from the First to Second Trimester of Pregnancy are Associated with Fetal Growth and Infant Length at Birth. Am J Clin Nutr 2004;79(4): 646-52.

20. Dewey KG, Begum K. Long-term Consequences of Stunting in Early Life. Maternal and Child Nutrition 2011;7(3): 5-18

21. Victora CG, Adair L, Fall C, Hallal PC, Martorell R, Richter L, Sachdev HS. Maternal and Child Undernutrition: Consequences for Adult Health and Human Capital. Lancet 2008;371(9606):340-57.

22. Allen LH, Gillespie SR. What works? A review of the efficacy and effectiveness of nutrition interventions. Manila: ADB; 2001. 
23. Asrar M, Hadi H, Boediman. Hubungan Pola Asuh, Pola Makan, Asupan Zat Gizi dengan Status Gizi Anak Balita Masyarakat Naulu di Kecamatan Amahai Kabupaten Maluku Tengah Provinsi Maluku. Jurnal Gizi Klinik Indonesia 2009;6(2):84-94.

24. Umeta M, West Clive E, Verhoef H, Haidar J, Hautvast JGAJ. Factors Associated with Stunting in Infants Aged 5-11 Months In the Dodota-Sire District, Rural Ethiopia. J Nutr 2003;133(4):1064-9.

25. Zein U, Ginting J, Sagala KH. Diare Akut disebabkan Bakteri. Medan: Fakultas Kedokteran Universitas Sumatera Utara; 2004.

26. UNICEF. Experts consultation on growth monitoring and promotion strategis: program guidance for a way forward. New York, USA: UNICEF; 2008.

27. Yuliana, Khomsan A, Patmonodewo S, Riyadi H, Muchtadi D. Pengaruh Penyuluhan Gizi dan Stimulasi Psikososial terhadap Pertumbuhan dan Perkembangan Anak Usia Pra Sekolah. Jurnal Gizi dan Pangan IPB. 2007.

28. Suhardjo. Berbagai Cara Pendidikan Gizi. Jakarta: Bumi Aksara; 2003.

29. Khomsan A, Anwar F, Mudjajanto ES. Pengetahuan, Sikap, dan Praktek Gizi Ibu Peserta Posyandu. Jurnal Gizi dan Pangan 2009;4(1):33-41.

30. Wahdah S. Faktor Resiko Kejadian Stunting pada Anak usia 6-36 bulan di Wilayah Pedalaman Kecamatan Silat Hulu Kabupaten Kapuas Hulu Provinsi Kalimantan Barat [Tesis]. Yogyakarta: Universitas Gadjah Mada; 2012.

31. Notosiswoyo M, Martomijoyo R, Supardi S, Riyadina W. Pengetahuan, Sikap dan Perilaku Ibu Bayi/Anak Balita serta Persepsi Masyarakat dalam Kaitannya dengan Penyakit ISPA dan Pneumonia. Buletin Penelitian Kesehatan 2003;31(2):60-71.

32. Katona $P$, Katona-Apte J. The Interaction between Nutrition and Infection. Clin Infect Dis 2008;46(10):1582-8. 